\title{
The Prevalence of Helicobacter pylori Infection and Its Associated Risk Factors Among Patients Undergoing Upper Gastrointestinal Diagnosis in Shashemene Referral Hospital in Shashemene, Ethiopia
}

\author{
Mulu Bekele Zufan Besewi Beyene Dobo \\ Hawassa University, Department of Biology, P. O. Box: 05, Hawassa, Ethiopia
}

\begin{abstract}
Background:- Helicobacter pylori infection is the principal cause of chronic active gastritis in developing countries including Ethiopia. Objective:- The main objective of the present study is to evaluate the prevalence of H. pylori infection colonization and its associated risk factors among upper gastrointestinal patients aged $\geq 14$ years. Method:- Hospital-based retrospective and cross-sectional study was conducted at Shashemene referral Hospital among upper gastrointestinal positive patients who underwent diagnosis in the Hospital from September 2012August 2017. Results:- After organizing the recorded data of the 1966 upper gastrointestinal patients, the overall prevalence of five consecutive years (September 2012-August 2017) H. pylori infection in this study was found to be $30.3 \%(n=592 / 1966)$. The majority of the patients were in the age range of $20-29(218 / 657(33.03 \%))$ and $\geq 60(46 / 149(30.9 \%))$. The overall prevalence of $H$. pylori in this study dropped from $45.5 \%$ in September 2012 August 2013 to 15.2\% in September 2016 - August 2017. The most important risk factors in this study were large family size, age, poor personal hygiene, poor hygiene in nutrition and life style, poor economic status, stress, alcohol, overcrowding and educational level. Marital status of the patients $(2.793$ OR; $95 \% \mathrm{CI}: \mathrm{p}=0.038<0.05)$ and age groups $(1.345 \mathrm{OR} ; 95 \% \mathrm{CI}: \mathrm{p}=0.006<0.05)$ were statistically significant predictors or were significantly associated with $H$. pylori infection. In this study the prevalence of $H$. pylori infection is highest in the youngest group, because of the exacerbation of the youngest to multi substance use, and environmental hygienic condition. Conclusion and recommendation:-This study has shown that gastritis and $H$. pylori infection were the major problems in the study area and, therefore, further in-depth epidemiological Oresearch and identification of other potential environmental and personal related risk factors of $H$. pylori infection and gastritis are suggested.
\end{abstract}

Keywords: Helicobacter Pylori; gastritis; prevalence; risk factor; Ethiopia; retrospective study; cross-sectional study

DOI: $10.7176 / \mathrm{JHMN} / 73-01$

Publication date: April $30^{\text {th }} 2020$

\section{INTRODUCTION}

Helicobacter pylori are a gram-negative, spiral-shaped, urease-producing bacterium with multiple unipolar flagella usually colonizes gastric pits under the mucus layer and in close association to gastric epithelial cells. Humans are a major reservoir for $H$. pylori. It is proven that $H$. pylori are the principal cause of chronic gastritis, peptic ulcer disease as well as gastric cancer (Sepulveda and Graham, 2002). Chronic gastritis and peptic ulceration are prevalent in a high magnitude throughout the world (Ghazzawi and Obidat, 2004). H. pylori are the principal cause of chronic active gastritis and have major complications like gastric adenocarcinoma and mucosa associated lymphoid tissue lymphoma (Ozbek et al., 2010).

H. pylori neutralize the acid in its environment by producing large amounts of urease, which breaks down the urea present in the stomach to carbon dioxide and ammonia, the ammonia then neutralizes stomach acid (Stingl et al., 2002). There are many other etiological factors such as smoking, non-steroidal anti-inflammatory drugs (NSAIDS), and reflux of gastric juice (chemical gastritis) that are also implicated to cause chronic gastritis. $H$. pylori, though is regarded as the primary cause of gastritis, it can act as a synergist in addition with other etiological factors (Parkin et al., 1999). A wide range of laboratory investigations are available for diagnosis of $H$. pylori. The tests belong to non-invasive group and invasive group. Non-invasive tests include urea breath test, serological Immunoglobulin $\mathrm{G}(\mathrm{IgG})$ and Immunoglobulin $\mathrm{M}$ (IgM) detection, saliva and urinary antibody test, and stool antigen test (Malfertheiner et al., 2007). The invasive tests are endoscopy based tests, which include histopathological examination, rapid urease test (RUT) and polymerase chain reaction. The role of non-invasive tests such as serology is limited in areas of high prevalence, because of non-distinction between previous and current infection (Graham and Sung, 2006).

Since H. pylori were first discovered by Warren and Marshall in 1983, it has radically changed our understanding and clinical management of gastro duodenal disease and much has been researched about its clinical aspects and its epidemiology (Suk, 2011). Its incidence and prevalence differs in relation to different factors like geography, age, and socio-economic factors high in developing countries and lower in the developed world (Veldhuyzen van zantel, 1995). Researchers found a consistent pattern in most developing nations, where 70 to 
$90 \%$ of adults harbored the bacteria; most individuals acquired the infection as children, before age ten (Hunt et al., 2011). Some studies have shown male predominance in infection, (Dhakhwa et al., 2012). Many patients still attribute symptoms of dyspepsia to diet, stress, and lifestyle factors; however, it is now proven that $H$. pylori is the principal cause of chronic gastritis and is strongly associated with peptic ulcer disease as well as gastric cancer, including gastric lymphoma (Aroori, 2001).

Ethiopia is one of the African countries in which the prevalence of the same infection is believed to be very high, which is probably attributed to the poor living conditions and overcrowding of the population (Alem Alemayehu, 2011). Study in Ethiopia 'Helicobacter pylori, gastritis and non-ulcer dyspepsia in Ethiopia patients' the prevalence of $H$. pylori infection in Ethiopia was in the range of 56\% - 70\% showed that the prevalence of $H$. pylori infection in Ethiopia was in the range of 56\% - 70\% (Tsega et al., 1996). Study in Ethiopia 'Prevalence of Helicobacter pylori infection among adult dyspeptic patients in Ethiopia' showed that the overall prevalence of $H$. pylori infection in adult dyspeptic patients between 69 and 91\% (Asrat et al., 2004).But recent study in Ethiopia 'Seroprevalence of Helicobacter pylori infection and its risk factors among adult patients in Hawassa Teaching and referral Hospital, south Ethiopia' showed that the range of the prevalence as being 62.5-91\% (Alem Alemayehu, 2011).

According to study by Abebaw et al. (2014), the higher cases of gastritis among the married respondents could also be due to stress experienced as people (married couples) start new independent life. The study at Jigjiga University, Jigjiga, Somali Regional State of Ethiopia, lack of awareness on the transmission ways of $H$. pylori was significantly associated with the prevalence of the infection $(\mathrm{p}=0.025)$ and those who had not awareness about the transmission ways of $H$. pylori had 2.53 times higher odds of being infected with this bacterium than aware participants (Alebie G and Kaba D, 2016). Shashemene is one of the towns in West Arsi zone Oromiya region. Some of the local people in this town and its surrounding use untreated underground water which is poor in sanitation. From personal observation and communication with the society, the researcher is able to recognize that most of the people are complaining of gastritis and there was no study done particularly in the present study area. Even though gastritis is not only caused by $H$. pylori infection, people do not seem to have the information about the fact that the gastritis is also caused by bacteria. Moreover, there is a common misconception in the area that the disease gastritis has no drug for treatment.

Many local people do not think that poor sanitation, use of unclean water, and unhygienic food could be factors for acquiring the disease. They often tend to believe that it is caused only by consuming spices, acidic or alkaline foods, exposure to stressful condition, drinking alcohol(Alcohol consumption is the world's third risk factor for diseases; in middle income countries, it is the greatest risk factor (WHO, 2011)), smoking, etc. As many studies indicate, H. pylori are a cause of peptic ulcer, gastric cancer and mucosal associated lymphoid tissue lymphoma. In West Arsi Zone, there were no several studies done on the prevalence of $H$. pylori infection and its major risk factors particularly in the present study area. Therefore, it is important to assess the prevalence of $H$. pylori infection and its associated factors to implement appropriate public health measures targeted against the disease. The study was conducted at Shashemene referral hospital in Ethiopia.

\section{MATERIALS AND METHODS}

\subsection{Description of the Study Area}

West Arsi Zone is located in the Oromia Region of Ethiopia. The Shashemene referral Hospital is located at 250 $\mathrm{km}$ south of Addis Ababa, in West Arsi Zone. This referral hospital serves a catchment area of more than 2.2 million people who are living in Shashemene, Arsi Negele, and other surrounding area. The hospital was established in 1952 by missionaries as Leprosy control and treatment center. In 1968 extended to hospital (Li'ilt Tenagne works Hospital). It was handed over to the government in 1976. At present it serves as a Referral Hospital in the region and provides health care services for 2.2 million population of the catchment area. Have 165 beds for inpatient services (Medical, surgical, Pediatrics, Eye, TB and leprosy.

\subsection{Study Design}

This study was hospital based five years (September 2012-August 2017) retrospective study which was conducted at Shashemene referral hospital and the prevalence of $H$. pylori among upper gastrointestinal positive patients was determined. In addition to this, a cross-sectional study was conducted at Shahsemene referral hospital and the risk factors of the $H$. pylori among upper gastrointestinal positive patients who were undergo diagnosis in the $\mathrm{H}=$ hospital from September 2016 to August 2017 was determined using questionnaire.

\subsection{Study Population}

The study population was comprised of all the upper gastrointestinal patients aged $\geq 14$ years old that were suspected for H. pylori infection and visited the laboratory in Shashemene referral hospital from September 2012 -August 2017. The majority of patients had dyspeptic symptoms, including epigastric pain or burning, nausea, belching, and bloating. The information on socio-demographic characteristics and other risk factors were collected 
from the study subjects (attending diagnosis in Shashemene referral hospital from September 2012 -August 2017) using structured questionnaire.

\subsection{Sample Size Determination and Sampling Method}

A 5 years retrospective data of patients undergoing upper gastrointestinal diagnosis in the Shashemene referral hospital from September 2012- Augest2017 were used. The information was collected from secondary data of the examined gastritis patients including H. pylori positive patient's documents recorded in the shashemene referral hospital from September 2012 - August 2017. The sample size for the cross sectional study was determined by using statistical formula and the information about risk factors was be collected from upper gastrointestinal patients that undergoing diagnosis in this Hospital from September 2016 to August 20017. The sample size was determined by using the formula provided by Daniel (2004) and the required sample size at $95 \%$ confidence level, and level of precision $(5 \%)$ was determined.

$$
\begin{aligned}
& \mathrm{n}=\mathrm{t}^{2} \frac{\mathrm{p}(1-\mathrm{p})}{(\mathrm{m}) 2} \text { Where, } \quad \mathrm{n}=\text { required sample size } \\
& \mathrm{t}=\text { confidence level at } 95 \%=1.96 \\
& \mathrm{p}=\text { estimated prevalence }=50 \%=\text { expected prevalence proportion }
\end{aligned}
$$

$\mathrm{m}=$ desired margin of error or measure of precision $=5 \%$ $\mathrm{n}=(1.96)^{2} \frac{0.5(1-0.5)}{(0.05) 2}=3.8416 \frac{0.25}{0.0025}=384.16=384$ and another $10 \%$ to minimize errors arising from the likelihood of non-responsive individuals, $10 \%$ of the sample size is added to the normal sample size allow, a total of 422.422 fresh stool samples were collected from 422 gastritis patients. Systematic random sampling method will be used to collect stool samples from both sexes and from different age groups.

\subsubsection{Stool Sample Collection and examination techniques}

This part of the study was done with the laboratory technicians. At the beginning of stool collection orientation regarding the handling and avoidance of contamination of stool specimens was given to all the subjects by senior laboratory technicians. Then disposable plastic cups with labels of their own unique codes and clean applicator sticks were provided to all respondents to collect fresh stool specimen. The resulting suspension was added to the sensitive test strip and examined for positive and negative results. This also used by (Shimoyama and Kato, 2009).

Standard procedure was used during stool sample collection. From each stool sample, small portions of the fecal material was taken using a sterile applicator stick which was screw on the collection tube and placed the stick in the tube and tighten securely. The samples was diluted using the extraction buffer (Buffer for H. pylori AG feces strip) contained in a vial and vigorously shaken by hand. The resulting diluted material will added in drops on to the test strip (H. pylori AG feces strip) and the results was read after 15 minutes according to the manufacture's instruction. Appearance of color band on the device on both test line and control line was interpreted as positive and as negative if it is only on the control line.

\subsubsection{Data Collection}

A total of 1966 subjects whose data were completely registered were included in the study. Five-year data from September 2012- August 2017 were taken from the serology log book in Shashemene referral hospital. Sociodemographic characteristics (age and sex) of the study subjects were collected using a checklist. Data of all consecutive individuals referred from outpatient as well as inpatient department which had undergone diagnosis for H. pylori infection and primary data from those visited the hospital in September 2016-August 2017 for various dyspeptic symptoms like pain abdomen, nausea, vomiting, belching, throat pain, upper gastrointestinal bleeding, weight loss, gastrointestinal symptoms. And copies of the structured questionnaire was distributed for 422 patient respondents to obtain information on socio-demographic factors; age, sex, residence, family size, educational level, monthly income, marital status and awareness about H. pylori. The questionnaire was developed in English and the translated in Afan Oromo (their local language). For those respondents who cannot read questionnaire items were read and their answers was immediately recorded by the researcher. Permission was taken from the hospital's staffs interviewed. The study was approved by the hospital ethical review committee.

\subsection{Data Analysis}

After the data have been collected, the raw data was analyzed. This was through coding and tabulation and then drawing statistical inference. Descriptive and frequency analysis of the data from the study was expressed as counts and percentage as appropriate to provide the overall picture. The data was analyzed using Statistical Package of Social Sciences (SPSS) version 20. Chi-square test with exact test was used where applicable. A p value of $<0.05$ was considered to denote statistical significance. Qualitative data obtained from various sources was examined and presented in different forms. It was discussed under different headings, narrated and summarized. Quantitative data was edited, coded and entered into computer using SPSS analyzed. Descriptive statistics, frequencies, percentage and chi-square was under taken. Multiple response questions were analyzed so as to give frequencies and percentages. The different variables were presented with the help of Tables and graphs. After analyzed, the result was interpreted and the research report was written to communicate information. The final results were 
reported.

\section{RESULTS AND DISCUSSION}

\subsection{Results}

3.1.1. The Prevalence of $\mathrm{H}$. Pylori infection colonization among upper gastrointestinal patients 3.1.1.1. Socio-Demographic Characteristics of the Study subjects

As can be observed from Table1, the number of female patients was $(64.6 \%)$ of which $(65.03 \%)$ was $H$. pylori positive and male patients $(35.4 \%)$ of which $(34.97 \%)$ were H. pylori positive. The higher positive for the infection is seen in female patients which is $65.03 \%$. The differences between $H$. pylori positivity of male and female subjects were not statistically significant $\left(\chi^{2}=0.020 ; P=0.465\right)$. Besides, the majority of the patients were in the age range of $20-29$ years $(33.6 \%)$ of which $(33.03 \%)$ was $H$. pylori positive and $\geq 60$ years $149(7.6 \%)$ of which $46(30.9 \%)$ was $H$. pylori positive. The highest positive for the infection is seen in $\geq 60$ year patients which is $30.9 \%$. The differences between $H$. pylori positivity among different age groups of the subjects were not statistically significant $\left(\chi^{2}=7.510 ; P>0.185\right)$. Likewise, majority $(60.3 \%)$ of the study participants of which $342(29 \%) H$. pylori positive were rural residents and $786(39.7 \%)$ patients of which $250(32 \%)$ was $H$. pylori positive were urban residents. The higher positive for the infection is seen in urban resident's patients which is $32 \%$. But, it is statistically not significant with the infection (Table1).

Table1. Socio-demographic characteristics of the study participants who visited shashemene referral Hospital from September 2012- August 2017 ( N=1966)

\begin{tabular}{llllllr}
\hline Character & Category & No. exam. $(\%)$ & Negative $(\%)$ & Positive $(\%)$ & $\chi^{2}$ & P-value \\
\hline Sex & Male & $692(35.4)$ & $485(65.03)$ & $207(34.97)$ & 0.020 & 0.465 \\
& Female & $1274(64.6)$ & $889(34.97)$ & $385(65.03)$ & & \\
Age groups & $20-29$ & $294(15)$ & $216(73.5)$ & $78(26.5)$ & 7.510 & 0.185 \\
& $30-39$ & $467(23.9)$ & $440(66.97)$ & $217(33.03)$ & & \\
& $40-49$ & $239(12.2)$ & $179(74.9)$ & $60(25.1)$ & & \\
& $50-59$ & $150(7.7)$ & $104(69.3)$ & $46(30.7)$ & & \\
Residential & $\geq 60$ & $149(7.6)$ & $103(69.1)$ & $46(30.9)$ & & \\
area & Urban & $786(39.7)$ & $536(68)$ & $250(32)$ & 1.787 & 0.181 \\
\hline
\end{tabular}

3.1.2. The Prevalence of $\mathbf{H}$. pylori Infection Colonization among Upper Gastrointestinal Patients from September 2012 - August 2017

This study has analyzed the Prevalence of H. pylori infection among different age groups and gender of year September 2012 - August 2017. As can be observed from Table1, among all the patients of five consecutive years, 692/1966 (35.4\%) were males and 1274/1966 (64.6\%) were females. Furthermore, the present study highlighted (figure1), 592/1966(30.3\%) are H. pylori positive, of which 207/592 (34.97\%) are males and 385/592 (65.03\%) are females. The higher positive for the infection is seen in female patients which is $65.03 \%$. The overall prevalence of five consecutive years (September 2012 - August 2017) H. pylori infection in this study was $30.30 \%$ $(n=592 / 1966)$

As shown in Figure3, exposure to H. pylori seems to be higher among participants in the age group $20-29$ years relatively (217) and lower among participants in the age group $\geq 60$. When we see the prevalence in different years, as can be seen from Table 2, the overall prevalence of $H$. pylori in this study drops from $45.5 \%$ in September 2012 - August 2013 to 15.2\% in September 2016 - August 2017. 
Table2. Prevalence of H. pylori among age and gender from September 2012-August 2017

\begin{tabular}{|c|c|c|c|c|c|c|c|}
\hline Year & $\begin{array}{l}\text { Age } \\
\text { group }\end{array}$ & $\begin{array}{l}\text { Gender } \\
\text { Male } \\
\text { No.exa }\end{array}$ & No.pos(\%) & $\begin{array}{l}\text { Female } \\
\text { No.exa. }\end{array}$ & No.pos.(\%) & $\begin{array}{l}\text { Both sex } \\
\text { No.exa. }\end{array}$ & No.pos.(\%) \\
\hline Sept.2012- & $<20$ & 18 & $9(50)$ & 79 & $32(40.5)$ & 97 & $41(42.3)$ \\
\hline \multirow[t]{6}{*}{ Aug.2013 } & $20-29$ & 84 & $42(50)$ & 171 & $84(49.1)$ & 255 & $126(49.4)$ \\
\hline & $30-39$ & 55 & $23(41.8)$ & 123 & $59(48)$ & 178 & $82(46.1)$ \\
\hline & $40-49$ & 28 & $14(50)$ & 57 & $23(40.4)$ & 85 & $37(43.5)$ \\
\hline & $50-59$ & 29 & $13(44.8)$ & 33 & $12(33.3)$ & 62 & $25(38.7)$ \\
\hline & $\geq 60$ & 34 & $21(61)$ & 15 & $4(26.6)$ & 59 & $25(42.4)$ \\
\hline & Total & 248 & $122(49.2)$ & 488 & $214(43.6)$ & 736 & $336(45.5)$ \\
\hline Sept.2013- & $<20$ & 20 & $4(20)$ & 42 & $2(2.8)$ & 62 & $6(9.7)$ \\
\hline \multirow[t]{6}{*}{ Aug.2014 } & $20-29$ & 38 & $8(21.1)$ & 91 & $38(26.5)$ & 129 & $46(35.7)$ \\
\hline & $30-39$ & 33 & $3(9.1)$ & 68 & $18(26.5)$ & 101 & $21(20.8)$ \\
\hline & $40-49$ & 22 & $3(13.6)$ & 38 & $4(10.5)$ & 60 & $7(11.7)$ \\
\hline & $50-59$ & 4 & $0(0)$ & 17 & $4(23.5)$ & 21 & $4(19.1)$ \\
\hline & $\geq 60$ & 17 & $5(29.4)$ & 10 & $3(30)$ & 17 & $8(47)$ \\
\hline & Total & 134 & $23(17.2)$ & 266 & $69(25.9)$ & 400 & $92(23)$ \\
\hline Sept.2014- & $<20$ & 5 & $1(20)$ & 18 & $2(11)$ & 23 & $3(13)$ \\
\hline \multirow[t]{5}{*}{ Aug.2015 } & $20-29$ & 17 & $1(5.9)$ & 20 & $5(25)$ & 37 & $6(16.2)$ \\
\hline & $40-49$ & 4 & $1(25)$ & 14 & $5(35.7)$ & 18 & $18(33.3)$ \\
\hline & $50-59$ & 2 & $1(50)$ & 9 & $5(55.6)$ & 11 & $6(54.5)$ \\
\hline & $\geq 60$ & 6 & $2(0)$ & 4 & $0(0)$ & 10 & $2(0)$ \\
\hline & Total & 40 & $7(15)$ & 88 & $23(26.1)$ & 128 & $30(22.7)$ \\
\hline Sept.2015- & $<20$ & 20 & $7(35)$ & 25 & $4(16)$ & 45 & $11(2.4)$ \\
\hline \multirow[t]{6}{*}{ Aug.2016 } & $20-29$ & 40 & $10(25)$ & 63 & $10(15.9)$ & 103 & $20(19.4)$ \\
\hline & $30-39$ & 26 & $9(34.6)$ & 34 & $6(17.6)$ & 60 & $15(25)$ \\
\hline & $40-49$ & 14 & $4(28.6)$ & 15 & $3(20)$ & 29 & $7(24.1)$ \\
\hline & $50-59$ & 7 & $2(28.6)$ & 17 & $7(41.2)$ & 24 & $9(3.5)$ \\
\hline & $\geq 60$ & 8 & $3(37.5)$ & 11 & $5(45.5)$ & 19 & $8(42.1)$ \\
\hline & Total & 115 & $35(30.4)$ & 165 & $35(21)$ & 280 & $70(25)$ \\
\hline Sept.2016- & $<20$ & 22 & $2(9.1)$ & 45 & $15(33.3)$ & 67 & $17(25.4)$ \\
\hline \multirow[t]{6}{*}{ Aug.2017 } & $20-29$ & 26 & $9(34.6)$ & 73 & $11(15.1$ & 99 & $20(20.2)$ \\
\hline & $30-39$ & 43 & $5(11.6)$ & 90 & $14(15.6)$ & 133 & $19(14.28)$ \\
\hline & $40-49$ & 18 & $1(5.6)$ & 27 & $3(11.1)$ & 45 & $4(8.9)$ \\
\hline & $50-59$ & 16 & $2(12.5)$ & 16 & 0 & 32 & $2(6.25)$ \\
\hline & $\geq 60$ & 30 & $1(3.33)$ & 16 & $1(6.3)$ & 46 & $2(4.35)$ \\
\hline & Total & 155 & $20(12.9)$ & 267 & $44(16.5)$ & 422 & $64(15.2)$ \\
\hline
\end{tabular}

Key: Sept., September, Aug., August, No. exam. Number of examined, No. pos. Number of positives

Regarding the sex-specific prevalence of $\mathrm{H}$. pylori, of the 248 male patients examined for $\mathrm{H}$. pylori from September 2012-August 2013, 122(49.2\%) were positive, and of the 488 female patients examined in the same year, 214(43.6\%) were found to be positive. The higher positive for the infection is seen in male patients which is $49.2 \%$. In this year the prevalence found higher in males than in females and was statistically significant $\left(\chi^{2}=4.986\right.$; $P=0.026)$. Similarly, the prevalence was higher in males $35(30.4 \%)$ than in females $35(21 \%)$ in the year Septembar2015-August 2016 was statistically significant $\left(\chi^{2}=3.675 ; P=0.049\right)$. However, the prevalence of $H$. pylori in the year September2014-August2015 was higher in females $23(26.1 \%)$ than in males 7(15\%) which was not statistically significant $\left(\chi^{2}=0.016 ; P=0.899\right)$. Similarly, the prevalence was higher in females $69(25.9 \%)$ than males $23(17.2 \%)$ in the year September2013-August 2014 and September 2016- August 2017 in females $44(16.5 \%)$ than in males 20(12.9\%), but both are not significant (Table 3). 
Table3. Year-specific percent distribution on prevalence of Helicobacter pylori among upper gastrointestinal symptomatic (dyspeptic) patients by sex at Shashemene Referral Hospital from September 2012-August 2017

\begin{tabular}{|c|c|c|c|c|c|c|c|c|}
\hline \multirow[t]{2}{*}{ Year } & \multicolumn{2}{|l|}{ Male } & \multicolumn{2}{|l|}{ Female } & \multirow{2}{*}{$\begin{array}{l}\text { Total } \\
\text { Exam. }\end{array}$} & \multirow{2}{*}{$\begin{array}{l}\text { Positive } \\
(\%)\end{array}$} & \multirow[t]{2}{*}{$\chi^{2}$} & \multirow{2}{*}{$\begin{array}{l}\text { P- } \\
\text { Value }\end{array}$} \\
\hline & Exam. & $\begin{array}{l}\text { Positive } \\
(\%)\end{array}$ & Exam. & $\begin{array}{l}\text { Positive } \\
(\%)\end{array}$ & & & & \\
\hline $\begin{array}{l}\text { Sept.2012- } \\
\text { Aug.2013 }\end{array}$ & 248 & $122(49.2)$ & 488 & $214(43.6)$ & 736 & $336(45.5)$ & 4.986 & 0.026 \\
\hline $\begin{array}{l}\text { Sept.2013- } \\
\text { Aug.2014 }\end{array}$ & 134 & $23(17.2)$ & 266 & $69(25.9)$ & 400 & $92(23)$ & 0.593 & 0.441 \\
\hline $\begin{array}{l}\text { Sept.2014- } \\
\text { Aug.2015 }\end{array}$ & 40 & $7(15)$ & 88 & $23(26.1)$ & 128 & $30(22.7)$ & 0.016 & 0.899 \\
\hline $\begin{array}{l}\text { Sept.2015- } \\
\text { Aug.2016 }\end{array}$ & 115 & $35(30.4)$ & 165 & $35(21)$ & 280 & $70(25)$ & 3.675 & 0.049 \\
\hline $\begin{array}{l}\text { Sept.2016- } \\
\text { Aug.2017 }\end{array}$ & 155 & $20(12.9)$ & 267 & $44(16.5)$ & 422 & $64(15.2)$ & 0.182 & 0.670 \\
\hline
\end{tabular}

Key: Sept., September, Aug., August, Exam. Examined, $\chi^{2}$, Chi-square, P-value, level of significance

The prevalence of $H$. pylori infection among the symptomatic patients in Shashemene referral Hospital in the year September 2012-August 2013 was $45.5 \%$. The prevalence decreased to $23 \%$ and $22.7 \%$ September 2013 August 2014 and September 2014-August 2015, respectively. However, there was some what a high increment in the year September 2015-August 2016 (25\%). The prevalence decreased again in the year September 2016-August 2017 was $15.2 \%$. And the frequency of the Patients was lower than the four previous years. Generally, in this study, the researcher found high but fluctuating prevalence of $H$. pylori infection among symptomatic patients (Table 3). 3.1.3. Prevalence of $\boldsymbol{H}$. Pylori Infection among Different Age and Gender Groups of Year September 2012August 2017

As it can be observed from the figure 6 below, the overall frequency of $H$. pylori infection among different gender and age groups from September 2012-August 2017 was $30.30 \%$. The distribution of colonization in $<20$ years, 2029 years, $30-39$ years, $40-49$ years, $50-59$ years, and $\geq 60$ years age groups was $26.53 \%, 33.03 \%, 31.05 \%, 25.1 \%$, $30.7 \%$, and $30.9 \%$ respectively. The majority of the patients were in the age range of $20-29(33.03 \%), 30-39$ $(31.05 \%), \geq 60(30.9 \%)$, and 50-59 (30.7) (Figure 6). As can be seen from figure 6, compared to the other age groups in both male and females, the age group 20-29 and 30-39 years old showed relatively higher prevalence. The prevalence of $H$. pylori in this study was highest in the $\geq 60$ age group (30.9\%) and lowest among $<20$ age group (26.5\%). Similarly, the overall prevalence among male and female was slightly similar $(29.9 \%$ and $30.2 \%$, respectively) (figure 6). As a general, during this consecutive five years the result indicated that the frequency of the infection is highest in the age range of $\geq 60$ (30.9\%) and age range of $20-29(33.03 \%)$ is the second highest.

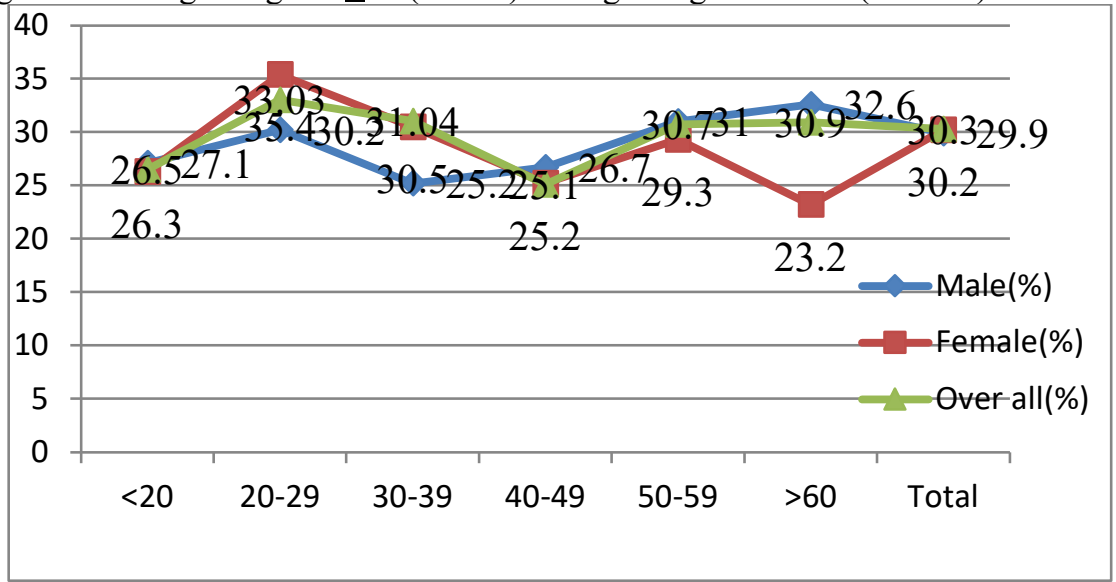

Figure 6. Prevalence of H. pylori among different gender and age groups of year September 2012 - August 2017 3.1.4. The Status of $\boldsymbol{H}$. pylori Infection in Shashemene Town and Its Surroundings from September 2012 to August 2017

As it can be observed from figure 7 below, the total frequency of $H$. pylori infection among the five years and gender from September 2012-August 2013 was higher in females (214) and 122 in males. In general, during this consecutive five years the results indicated that the frequency of the infection was highest in the first year September 2012-August 2013 (336) and decreased in the next 4 years. 


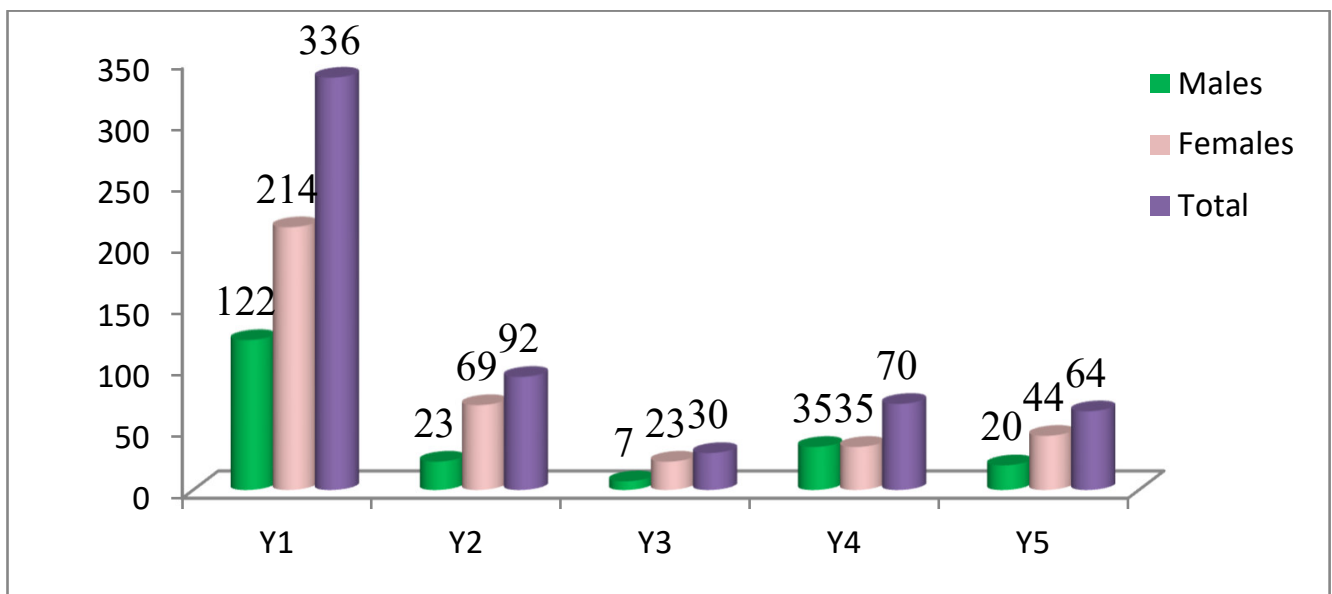

Figure7. The Status of H. pylori Infection among the study participants Who Visited Shashemene Referral Hospital from September 2012 to August 2017. Y1- Sep.2012-Aug.2013; Y2- Sep.2013-Aug.2014;Y3- Sep.2014Aug.2015;Y4- Sep.2015-Aug.2016;Y5- Sep.2016-Aug.2017

3.1.5. H. pylori Infection and Its Associated Risk Factors among Patients Undergoing Upper Gastrointestinal Diagnosis in Shashemene Referral Hospital from September 2016 to August 2017 3.1.5.1. Prevalence of $H$. pylori Infection among Gastritis Patients Visiting Shashemene Referral Hospital from September 2016 to August 2017

As shown in the figure below, of a total of 422 study participants, $84.8 \%$ negative and overall $15.2 \%$ antigens of H. pylori were detected.

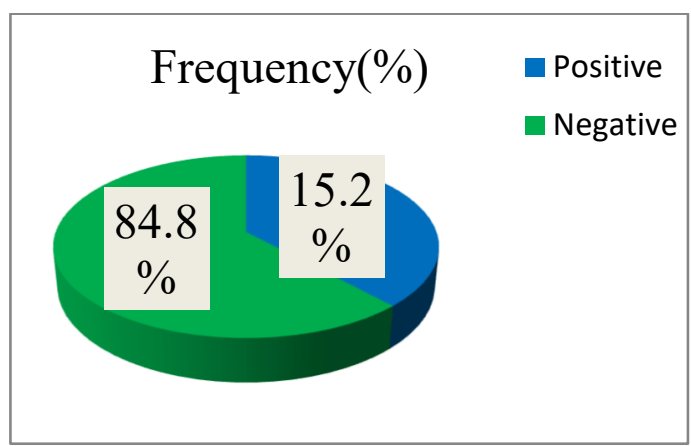

Figure 8. Frequency and percentage of the gastritis patients visiting Shashemene referral hospital from September 2016 to August 2017

The prevalence of $H$. pylori infection by age among gastritis patients visiting Shashemene referral hospital from September 2016 to August 2017 is shown in table 4 below. The majority of the respondents were in the age range of 30-39 years $133(31.5 \%)$ and 20-29 years 99(23.5\%) (Table4). For this the relationship across 6 age groups of patients were examined, the highest positive for the infection is seen in age group less than 20 which is $25.4 \%$. For the participants it can be seen that the test statistic value for Pearson chi-square is $14.997,5$ degrees of freedom and, as the $p$ value is smaller than 0.005 , it was concluded that there is a significant association between the infection and this age group.

The prevalence of $H$. pylori infection by sex among gastritis patients visiting Shashemene referral hospital from September 2016 to August 2017 is also showed in the table 4 below. The results showed that the number of female was higher $267(63.3 \%)$ of which $44(16.9)$ were $H$. pylori positive than male patients $155(36.7 \%)$ of which $20(13.5 \%)$ were H. pylori positive males and 44(16.9\%) females (Table 4).For this the relationship across 2 groups of patients, males and females were examined, the highest positive for the infection is seen in females which is $16.9 \%$. For the participants it can be seen that the test statistic value for Pearson chi-square is $0.975,1$ degrees of freedom and, as the $p$ value is greater than 0.005 , then it can be concluded that the association of the infection and the different sex group is not statistically significant.

The prevalence of $H$. pylori infection by level of by family size among gastritis patients visiting Shashemene referral hospital from September 2016 to August 2017 is shown in the table 4 below. Most of the study participants have family size of $\geq 4$ that was $372(88.2 \%)$ persons per house hold only $50(11.8 \%)$ study participants have family size of $<4$. For this the relationship across 2 groups of patients, $<4$ and $\geq 4$ family size were examined, the highest positive for the infection is seen in the Family size of $\geq 4$ which is (88.2\%). For the participants it can be seen that the test statistic value for Pearson chi-square is $0.060,1$ degrees of freedom and, as the $p$ value is greater than 
0.005 , then it can be concluded that this pattern of scores is not significant.

The Prevalence of $H$. pylori infection by educational level among gastritis patients visiting Shashemene referral hospital from September 2016 to August 2017 is shown in the table 4 below. The majority of the participants were able to read and write $311(73.7 \%)$ while the rest were illiterate $30(7.1 \%)$ and diploma and above $81(19.2 \%)$ of which Illiterate $5(16.7 \%)$, read and write $45(14.5 \%)$, diploma and above $14(17.3 \%)$ are H. pylori patients (Table 4). For this the relationship across 3 groups of patients, Illiterate, Can read and write and diploma and above were examined, the highest positive for the infection is seen in those diploma and above which is $14(17.3 \%)$. For the participants it can be seen that the test statistic value for Pearson chi-square is $0.452,2$ degrees of freedom and, as the $p$ value is greater than 0.05 , then it can be concluded that this pattern of scores is not significant.

The prevalence of $H$. pylori infection by Monthly income among gastritis patients visiting shashemene referral hospital from September 2016 to August 2017 is shown in the table 4 below. Most of the study participants have monthly income of $<700$ ETB $292(69.2 \%)$ of which $40(13.7 \%)$ are $H$. pylori positive and the rest $130(30.8 \%)$ of which 24(18.55\%) are $H$. pylori positive have Monthly income of $\geq 700$ ETB.But those with $\geq 700$ ETB monthly income $24(18.55 \%)$ were relatively higher $H$. pylori positivity. For the participants it can be seen that the test statistic value for Pearson chi-square is $1.586,1$ degrees of freedom and, as the $p$ value is greater than 0.005 , then it can be concluded that this pattern of scores is not significant.

Table 4. Association of socio-demographic and socioeconomic factors with prevalence of H. pylori infection in gastritis patients in Shashemene Referral hospital from September 2016 August 2017

\begin{tabular}{|c|c|c|c|c|c|c|}
\hline & & Total $(\%)$ & $\begin{array}{l}\text { No. H.pylori } \\
+ \text { ve }(\%)\end{array}$ & $\chi^{2}$ & $\mathrm{df}$ & $\mathrm{P}$ value \\
\hline \multirow{6}{*}{ Age group } & $<20$ & $67(15.9)$ & $17(25.4)$ & 14.997 & 5 & 0.010 \\
\hline & $20-29$ & $99(23.5)$ & $20(20.2)$ & & & \\
\hline & $30-39$ & $133(31.5)$ & $19(14.3)$ & & & \\
\hline & $40-49$ & $45(10.7)$ & $4(8.9)$ & & & \\
\hline & $50-59$ & $32(7.6)$ & $2(6.3)$ & & & \\
\hline & $>59$ & $46(10.9)$ & $2(4.3)$ & & & \\
\hline \multirow{4}{*}{$\begin{array}{l}\text { Food usually } \\
\text { pain }\end{array}$} & raw vegetable & $138(32)$ & $23(16.7)$ & 1.110 & 3 & 0.775 \\
\hline & protein rich food & $201(47.6)$ & $31(15.4)$ & & & \\
\hline & Carbohydrate rich food & $2(.5)$ & $0(0)$ & & & \\
\hline & Fats and oils & $81(19.2)$ & $10(12.3)$ & & & \\
\hline \multirow{3}{*}{ Educational level } & Illiterate & $30(7.1)$ & $5(16.7)$ & 0.425 & 2 & 0.798 \\
\hline & Can read and write & $311(73.7)$ & $45(14.5)$ & & & \\
\hline & Diploma and above & $81(19.2)$ & $14(17.3)$ & & & \\
\hline \multirow{2}{*}{ Sex of the patient } & Male & $155(36.7)$ & $20(13.5)$ & 0.975 & 1 & 0.323 \\
\hline & Female & $267(63.3)$ & $44(16.9)$ & & & \\
\hline \multirow{2}{*}{ Family size } & $<4$ & $50(11.8)$ & $7(14)$ & 0.060 & 1 & 0.807 \\
\hline & $\geq 4$ & $372(88.2)$ & $57(15.3)$ & & & \\
\hline \multirow{2}{*}{ Monthly income } & $<700 \mathrm{ETB}$ & $292(69.2)$ & $40(13.7)$ & 1.586 & 1 & 0.208 \\
\hline & $\geq 700 \mathrm{ETB}$ & $130(30.8)$ & $24(18.5)$ & & & \\
\hline
\end{tabular}

\subsubsection{Respondents' level of perceptions on factors aggravating gastritis}

Responses of study participants to some possible factors that might aggravate gastritis visiting Shashemene referral hospital from September 2016 to August 2017 are shown in the table 5 below. For this the relationship across 5 groups of patients, smoking, drinking alcohol, Eating spicy food, hunger, stress and anger were examined, the highest positive for the infection is seen in patients with stress and anger which is 34(17.4\%) and Eating spicy food which is $13(16.1 \%)$. For the participants it can be seen that the test statistic value for Pearson chi-square is $4.158,1$ degrees of freedom and, as the $p$ value is greater than 0.005 , then it can be concluded that this pattern of scores is not significant.

Table 5: Distribution of some possible factors aggravating H. pylori positive gastritis among the study participants

\begin{tabular}{lllllll}
\hline & & Total (\%) & $\begin{array}{l}\text { No. H.pylori } \\
+ \text { ve }(\%)\end{array}$ & $\chi^{2}$ & df & P value \\
\hline Gastritis & smoking & $17(4)$ & $2(11.8)$ & 4.158 & 4 & 0.323 \\
aggravate & drinking alcohol & $16(3.8)$ & $0(0)$ & & \\
& Eating spicy food & $81(19.2)$ & $13(16.1)$ & & \\
& Hunger & $113(26)$ & $15(13.3)$ & & \\
& Stress and anger & $195(46.2)$ & $34(17.4)$ & & \\
\hline
\end{tabular}

3.1.5.3. The proportions of respondents exposed to potential risk factors that contributed to $H$. pylori infection

The proportion of respondents exposed to factors that might have contribution to $H$. pylori infection is shown in 
table 6. The percentage of respondents who had good awareness about their personal hygiene and environmental sanitation $81(19.2 \%)$ was lower than that of the respondents who had poor awareness about their personal hygiene and environmental sanitation $341(80.8 \%)$. But, the highest positive for the infection is seen in respondents who had good awareness about their personal hygiene and environmental sanitation which is $17(21 \%)$.

The percentage of respondents who had awareness about $H$. pylori were 81(19.2) of which 13(16.0) were $H$. pylori positive and those who had no awareness about $H$. pylori were 341(80.8) of which 51(15) were H. pylori positive. But, the highest positive for the infection is seen in respondents who had awareness about $H$.pylori which is $13(16.0)$.

The source of water used by most respondents was unprotected well water 178(42.2\%). Only 139 (32.9\%) of the respondents were obtaining their drinking water from tap water. The highest positive for the infection is seen in respondents who used spring water which is $26.3 \%$. As the $p$ value is greater than 0.005 , then it can be concluded that this pattern of scores is statistically not associated with the infection.

Most of them had no toilet 260(61.6\%) of which 37(14.2\%) were H. pylori positive and only $162(38.4 \%)$ had toilet of which $27(16.7 \%)$. The highest positive for the infection is seen in respondents who had toilet which is $16.7 \%$. As the $p$ value is greater than 0.005 , then it can be concluded that this pattern of scores is statistically not associated with the infection.

About 259 (61.4\%) of the respondents were from rural of which 37(14.3) were H.pylori positive and 163(38.6) were from urban of which $27(16.6 \%)$ were H.pylori positive. The highest positive for the infection is seen in patients from urban of which is $16.6 \%$. As the $p$ value is greater than 0.005 , then it can be concluded that this pattern of scores is statistically not associated with the infection.

Interestingly, the majority $244(57.8 \%$ ) of the respondents of which $35(14.3 \%)$ were $H$. pylori positive revealed that they do not share utensils with their family members and $178(42.2 \%)$ of the respondents of which $51(28.7 \%)$ H.pylori positive were share utensils with their family members. The highest positive for the infection is seen in patients do not share utensils with their family members which were $28.7 \%$ (table 6). As the $p$ value is greater than 0.005 , then it can be concluded that this pattern of scores is statistically not associated with the infection.

Table6: Association of personal habits with prevalence of $H$. pylori infection in gastritis patients in Shashemene referral hospital from September 2016- August2017

\begin{tabular}{|c|c|c|c|c|c|c|}
\hline & & Total (\%) & $\begin{array}{l}\text { No. H.pylori } \\
\text { +ve }(\%)\end{array}$ & $\chi^{2}$ & $\mathrm{df}$ & $P$ value \\
\hline \multirow[t]{2}{*}{ Have toilet } & Yes & $162(38.4)$ & $27(16.7)$ & \multirow[t]{2}{*}{0.460} & \multirow[t]{2}{*}{1} & \multirow[t]{2}{*}{0.497} \\
\hline & No & $260(61.6)$ & $37(14.2)$ & & & \\
\hline \multirow{2}{*}{$\begin{array}{l}\text { Awareness about } H \text {. } \\
\text { pylori }\end{array}$} & Yes & $81(19.2)$ & $13(16.0)$ & \multirow[t]{2}{*}{0.061} & \multirow[t]{2}{*}{1} & \multirow[t]{2}{*}{0.805} \\
\hline & No & $341(80.8)$ & $51(15)$ & & & \\
\hline Share utensils & Yes & $178(42.2)$ & $51(28.7)$ & \multirow[t]{2}{*}{0.61} & \multirow[t]{2}{*}{1} & \multirow[t]{2}{*}{0.805} \\
\hline gastritis patients in home & No & $244(57.8)$ & $35(14.3)$ & & & \\
\hline Awareness of personal & poor & $341(80.8)$ & $47(13.8)$ & \multirow[t]{2}{*}{2.641} & \multirow[t]{2}{*}{1} & \multirow[t]{2}{*}{0.104} \\
\hline $\begin{array}{l}\text { hygiene and } \\
\text { environmental sanitation }\end{array}$ & good & $81(19.2)$ & $17(21)$ & & & \\
\hline \multirow[t]{2}{*}{ Place of residence } & Urban & $163(38.6)$ & $27(16.6)$ & \multirow[t]{2}{*}{0.404} & \multirow[t]{2}{*}{1} & \multirow[t]{2}{*}{0.525} \\
\hline & rural & $259(61.4)$ & $37(14.3)$ & & & \\
\hline \multirow[t]{4}{*}{ Use drinking water from } & River & $67(15.9)$ & $8(11.9)$ & \multirow[t]{4}{*}{4.653} & \multirow[t]{4}{*}{3} & \multirow[t]{4}{*}{0.199} \\
\hline & well water & $178(42.2)$ & $24(13.5)$ & & & \\
\hline & spring water & $38(9)$ & $10(26.3)$ & & & \\
\hline & tap water & $139(32.9)$ & $22(15.8)$ & & & \\
\hline
\end{tabular}

3.1.5.4. Association between Prevalence of H. Pylori Infections and Its Major Associated Risk Factors among Gastritis Patients Visiting Shashemene Referral Hospital from September 2012- August 2017

The distribution of $H$. pylori in different risk factors is indicated in Table 7. Of different risk factors considered in this study, marital status of the patients accounted the bigger number $(2.793$ OR; $95 \% \mathrm{CI}: \mathrm{p}=0.038<0.05)$. This is statistically significant predictors or was significantly associated with $H$. pylori infection. The higher cases of gastritis among the married respondents could also be due to stress experienced as people (married couples) start new independent life. The next largest value was for age groups $(1.345 \mathrm{OR} ; 95 \% \mathrm{CI}$ : $\mathrm{p}=0.006<0.05)$ which is also significantly associated with the infection. Age groupsand marital status were one and two times more likely associated with the infection $H$. pylori. The third next largest value is sharing of utensils accounted the bigger number $(1.431 \mathrm{OR} ; 95 \% \mathrm{CI}: \mathrm{p}=0.403>0.05)$. However, this is not statistically significant predictors or is not significantly associated with $H$. pylori infection. Most of the study participants were from rural residents 259 (61.4\%) (Table7). For this the relationship across 2 groups of patients, urban and rural were examined. For the participants it can be seen that the $p$ value is greater than 0.005 , then it can concluded that this pattern of scores is not significant. Other risk factors like family size, monthly income, gastritis aggravate,awareness of personal hygiene and environmental sanitation, usually wash hands with soap after latrine, awareness about $H$. pylori, having 
toilet,food usually makes pain and source of drinking water were not statistically significant $(\mathrm{P}>0.05)$ or were not significantly associated with $H$. pylori infection.

Table7. Association, prevalence of $H$. pylori infection and socio-economic, socio-demographic and personal habits factors with prevalence of $H$. pylori infection in gastritis patients in Shashemene referral hospital from September 2016- August 2017

\begin{tabular}{|c|c|c|c|c|c|c|}
\hline & $\begin{array}{l}\text { Total } \\
(\%)\end{array}$ & $\begin{array}{l}\text { No.of } \\
\text { H.pylori } \\
+ \text { ve }(\%)\end{array}$ & $\operatorname{Exp}(B)$ & $\begin{array}{l}95 \% \\
\text { EXP(B) } \\
\text { Lower }\end{array}$ & $\begin{array}{l}\text { CI.for } \\
\text { Upper }\end{array}$ & $\begin{array}{l}\mathrm{p} \text { - } \\
\text { value }\end{array}$ \\
\hline \multicolumn{7}{|l|}{ Age group } \\
\hline$<20$ & $67(15.9)$ & $17(25.4)$ & 1.345 & 1.090 & 1.660 & 0.006 \\
\hline $20-29$ & $99(23.5)$ & $20(20.2)$ & & & & \\
\hline $30-39$ & $133(31.5)$ & $19(14.3)$ & & & & \\
\hline $40-49$ & $45(10.7)$ & $4(8.9)$ & & & & \\
\hline $50-59$ & $32(7.6)$ & $2(6.3)$ & & & & \\
\hline$>59$ & $46(10.9)$ & $2(4.3)$ & & & & \\
\hline \multicolumn{7}{|l|}{ Sex of the patient } \\
\hline Male & $155(36.7)$ & $20(13.5)$ & 0.913 & 0.505 & 1.650 & 0.763 \\
\hline Female & $267(63.3)$ & $44(16.9)$ & & & & \\
\hline \multicolumn{7}{|l|}{ Place of residence } \\
\hline Urban & $163(38.6)$ & $27(16.6)$ & 1.089 & 0.308 & 3.856 & 0.895 \\
\hline Rural & $259(61.4)$ & $37(14.3)$ & & & & \\
\hline \multicolumn{7}{|l|}{ Family size } \\
\hline$<4$ & $50(11.8)$ & $7(14)$ & 0.854 & 0.280 & 2.606 & 0.781 \\
\hline$\geq 4$ & $372(88.2)$ & $57(15.3)$ & & & & \\
\hline \multicolumn{7}{|l|}{$\overline{\text { Educational level }}$} \\
\hline Illiterate & $30(7.1)$ & $5(16.7)$ & 1.283 & 0.528 & 3.120 & 0.582 \\
\hline Can read and write & $311(73.7)$ & $45(14.5)$ & & & & \\
\hline Diploma and above & $81(19.2)$ & $14(74.3)$ & & & & \\
\hline \multicolumn{7}{|l|}{ Monthly income } \\
\hline$<700$ ETB & $292(69.2)$ & $40(13.7)$ & 1.072 & 0.356 & 3.226 & 0.901 \\
\hline$\geq 700 \mathrm{ETB}$ & $130(30.8)$ & $24(18.5)$ & & & & \\
\hline \multicolumn{7}{|c|}{$\overline{\text { Marital status of the patients }}$} \\
\hline Married & $246(58.3)$ & $44(17.9)$ & 2.793 & 1.057 & 7.380 & 0.038 \\
\hline Not married & $176(41)$ & $20(11.4)$ & & & & \\
\hline \multicolumn{7}{|l|}{ Gastritis aggravate } \\
\hline Smoking & $17(4)$ & $2(11.8)$ & 0.746 & 0.505 & 1.103 & 0.142 \\
\hline Drinking alcohol & $16(3.8)$ & $0(0)$ & & & & \\
\hline Eating spicy food & $81(19.2)$ & $13(16.1)$ & & & & \\
\hline Hunger & $113(26)$ & $15(13.3)$ & & & & \\
\hline Stress and anger & $195(46.2)$ & $34(17.4)$ & & & & \\
\hline \multicolumn{7}{|c|}{ Food usually makes pain } \\
\hline Raw vegetable & $138(32)$ & $23(16.7)$ & 1.071 & 0.778 & 1.475 & 0.673 \\
\hline protein rich food & $201(47.6)$ & $31(15.4)$ & & & & \\
\hline Carbohydrate rich food & $2(.5)$ & $0(0)$ & & & & \\
\hline Fats and oils & $81(19.2)$ & $10(12.3)$ & & & & \\
\hline \multicolumn{7}{|c|}{ Use drinking water from } \\
\hline River & $67(15.9)$ & $8(11.9)$ & 0.681 & 0.387 & 1.198 & 0.182 \\
\hline well water & $178(42.2)$ & $24(13.5)$ & & & & \\
\hline spring water & $38(9)$ & $10(26.3)$ & & & & \\
\hline Tap water & $139(32.9)$ & $22(15.8)$ & & & & \\
\hline \multicolumn{7}{|l|}{ Sharing of utensils } \\
\hline yes & $341(80.8)$ & $51(15)$ & 1.431 & 0.618 & 3.310 & 0.403 \\
\hline no & $81(19.2)$ & $13(16)$ & & & & \\
\hline \multicolumn{7}{|c|}{ Awareness about $H$. pylori } \\
\hline yes & $81(19.2)$ & $13(16.0)$ & 0.910 & 0.313 & 2.643 & 0.862 \\
\hline No & $341(80.8)$ & $51(15)$ & & & & \\
\hline \multicolumn{7}{|l|}{ Have toilet } \\
\hline yes & $162(38.4)$ & $27(16.7)$ & 0.704 & 0.227 & 2.180 & 0.543 \\
\hline No & $260(61.6)$ & $37(14.2)$ & & & & \\
\hline
\end{tabular}




\section{Usually wash hands with soap after latrine \\ yes}

No

Awareness of personal hygiene
environmental sanitation
poor

good

$$
\text { 178(42.2) 29(16.3) }
$$

$244(57.8) 35(14.3)$

and

341(80.8) 47(13.8)

$81(19.2) \quad 17(21)$
0.773

0.237

2.516

0.669

0.616

0.197

1.928

0.406

\subsection{DISCUSSION}

In the current study, the five consecutive year's prevalence of the H. pylori infection and its associative risk factors examined and a Socio-Demographic characteristic of the study Patients was noticed. The number of female patients was $64.6 \%$ of which $65.03 \%$ was $H$. pylori positive and male patients was $35.4 \%$ of which $34.97 \%$ was H. pylori positive. The higher positive for the infection is seen in female patients which is $65.03 \%$. The differences between $H$. pylori positivity of male and female subjects in the current study was not statistically significant $(P=0.465)$. In line with this study finding, the study done by Khan et al. (2017) showed sex specific prevalence in female was $61.6 \%$ which was significantly high from that of males $38.4 \%$. Furthermore, it is also parallel to the study reported by Alebie G and Kaba D (2016) that showed the prevalence among male was $68.5 \%$ and among female was $75.5 \%$ but, gender was not significantly associated with H. pylori infection $(\mathrm{p}=0.371)$.

The majority of the patients were in the age range of $\geq 60$ years of which $30.9 \%$ was $\mathrm{H}$. pylori positive and 20 29 years of which $33.03 \%$ was $H$. pylori positive. The highest positive for the infection is seen in 20-29 year patients which is $33.03 \%$. The differences between $H$. pylori positivity among different age groups of the subjects were not statistically significant $(P>0.185)$, which is parallel to the study by Khan et al. (2017) age wise distribution showed maximum prevalence in the age group of $15-25$ years $(84.2 \%)$ followed by $>65$ years $(83 \%)$.

Majority $(60.3 \%)$ of the study participants of which $29 \% \mathrm{H}$. pylori positive wererural residents and $39.7 \%$ patients of which $32 \% \mathrm{H}$. pylori positive were urban residents. The higher positive for the infection is seen in urban resident's patients which is $32 \%$. However, it was statistically not significant with the infection. Interestingly, among all the symptomatic patients of five consecutive years, the $30.3 \%$ were $H$. pylori positive, of which $34.97 \%$ are males and $65.03 \%$ are females. However, recent population and hospital based studies in different parts of Ethiopia showed that the prevalence ranged 62.5-91\% (Alem Alemayehu, 2011).

According to study by Hunt et al. (2011), one half of the world's population has $H$. pylori infection, with an estimated prevalence of more than $90 \%$ in developing countries. The overall prevalence of five consecutive years (September 2012 - August 2017) H. pylori infection recorded in this study was $30.3 \%$, which is slightly similar to the figures reported in Canada 29.4\% (Naja et al., 2007). This lower prevalence can be explained by the fact that the researcher has estimated prevalence of $H$. pylori infection in symptomatic patients only. Several studies showed conflicting findings, it is lower in comparison to a study conducted in a tertiary care hospital in India, 208 individuals were screened for Helicobacter pylori which were positive in $44.23 \%$ of both symptomatic and asymptomatic individuals (Rastogi et al., 2015). Similarly, the result of current study was lower than the figure reported in Ethiopia range from56-70\% (Tsega et al., 1996). It is also not agreed with results reported from Ethiopia and elsewhere; 49- 70\% in Bair Dar (Tadege et al., 2005), 47\% in Karachi (Jafri et al., 2010); 49.7\% in Kuwait (Alazmi et al., 2010) and 46.6\% in Iran (Jafarzadeh et al., 2017). The finding was also lower than other results reported from Ethiopia; 83.3\% in Hawassa ( Tadesse et al. 2014); 81 -89\% in Addis Ababa (Asrat et al., 2004, Desta et al., 2007 ); 85.6\% in Gondar (Moges et al., 2006) and elsewhere in the world, 66\% in Kenya (Shmuely et al., 2003). Further, the present finding was found to be lower than the figures reported in Greenland $43 \%$ (Koch et al., 2005).

The overall prevalence of $H$. pylori in this study drops from $45.5 \%$ in September 2012 - August 2013 to $15.6 \%$ in September 2016 - August 2017. McJunkin et al. (2011) also reported a dramatic drop in H. pylori prevalence from $65.8 \%$ to $6.8 \%$ over an 11 -year period. Regarding the sex-specific prevalence of $H$. pylori, of the male patients examined for $H$. pyloriSeptember2012-August 2013, 49.2\% were positive, and of the female patients examined in the same year, $43.6 \%$ were found to be positive. The higher positive for the infection is seen in male patients which is $49.2 \%$. In this year the prevalence found higher in males than in females was statistically significant $\left(\chi^{2}=4.986 ; P=0.026\right)$. Similarly, the prevalence was higher in males $30.4 \%$ than in females $21 \%$ in the yearSeptember2015-August2016 was statistically significant $(P=0.049)$. However, the prevalence of $H$. pylori in the year September2014-August2015 was higher in females $26.1 \%$ than in males $15 \%$ which was not statistically significant $(P=0.899)$. Similarly, the prevalence was higher in females $25.9 \%$ than males $17.2 \%$ in the yearSeptember2013-August2014 and September 2016- August 2017 in females 16.5\% than in males 12.9\%, but both are not significant.

Approximately, $50 \%$ of the normal populations across the world harbor $H$. pylori, though only $10-20 \%$ of them become symptomatic (Omunakwe et al., 2011). The prevalence of $H$. pylori infection among the symptomatic 
patients in Shashemene referral Hospital in the year September 2012-August 2013 was 45.5\%.The prevalence decreased to 23\% and 22.7\%September 2013-August 2014 and September 2014-August 2015, respectively. However, there was some what a high increment in the year September 2015-August 2016was 25\%. The prevalence decreased again in the year September 2016-August 2017 was $15.2 \%$. And the frequency of the Patients was lower than the four previous years. Generally, in this study, the researcher found high but fluctuating prevalence of $H$. pylori infection among symptomatic patients.

The distribution of colonization in $<20$ years, 20-29 years, 30-39 years, 40-49 years, 50-59 years, and $\geq 60$ years age groups was $26.53 \%, 33.03 \%, 31.05 \%, 25.1 \%, 30.7 \%$, and $30.9 \%$ respectively. The majority of the patients were in the age range of 20-29 (33.03\%), 30-39 (31.05\%), $\geq 60(30.9 \%)$, and 50-59(30.7\%).In line with current findings, Hunt et al. (2011) also found that in most developing nations, 70 to $90 \%$ of adults harbored the bacteria. In contrast, a similar Indian study conducted by Kumar et al.(2006) showed maximum prevalence in the age group of 36-45 years (43.47\%) and minimum in the age group of 66-75 years (3.26\%).According to Ddine et al. (2012), in situations where there is high stress and anxiety, the secretion of $\mathrm{HCl}$ increases and causes erosion of the stomach. Compared to the other age groups in both male and females, the age group 20-29 and 30-39 years old showed relatively higher prevalence showing the uniqueness of the age groups in the lifestyle because these were the ages at which most people in Ethiopia shoulder family and social responsibilities and hence encounter real challenges in life which in turn might lead to stressful can change gastric motility, a very hot intake leads to congestion (burden) of mucosa and raise the secretion of acid. This result is in agreement with the study by Khan et al.(2017) age wise distribution showed maximum prevalence in the age group of $15-25$ years $84.2 \%$ followed by $>65$ years $83 \%$ and minimum in the age group of 55-65 (25\%).

The increase in prevalence observed in this study from young age $<20(26.5 \%)$ to adult age $\geq 60(30.9 \%)$ for both sexes. Similarly, Alem Alemayehu (2011) reported that $H$. pylori infection rate was higher in adult population than in children and that the prevalence increased with age. The prevalence of $H$. pylori infection in this study was highest in the $\geq 60$ age group $30.9 \%$ and lowest among $<20$ age group $26.5 \%$ which is similar to the study by Ozen et al. (2011), on children and adolescents in Asia showed prevalence rates ranging from $20 \%$ to $84 \%$. Similarly, the overall prevalence among male and female in this study was slightly similar $29.9 \%$ and $30.5 \%$, respectively.This is consistent with studies in Ethiopia (Tadege et al., 2005, Mathewos et al., 2013, Tadesse et al., 2014). But it is inconsistent with the study (Khan et al. 2017) in which sex specific prevalence in female was $61.6 \%$ which was significantly high from that of males $38.4 \%$. It is also not in agreement with previous studies shown by others in Kenya (Shmuely et al. 2003), and Ethiopia (Abebaw et al., 2014).

The total frequency of $H$. pylori infection in September 2012-August 2013, September 2013-August 2014 and September 2014-August 2015 were $45.5 \%, 23 \%$ and $22.7 \%$ respectively. And the majority of the patients in the previous two years were in the age range of 20-29 (56\%), 30-39 (46\%) and 20-29 (35.7\%), 30-39(20.8\%) respectively. And the frequencies of the patients in September 2014-August 2015 were lower than the previous two years. The total frequency of $H$. pylori infection in September 2015-August 2016 was 25\%. And the majority of the Patients were in the age range of $\geq 60(42.1 \%)$ and 30-39 (25\%). The total frequency of H. pylori infection in September 2016-August 2017 was 15.2\%. And the frequency of the Patients was lower than the four previous years. In the age range of $<20(25.4 \%)$ and 20-29 (20.2\%), it is higher relatively. This evidence showed that the infection is decreasing. Interestingly, the overall frequency (prevalence) of $H$. pylori infection among different gender and age groups from September 2012-August 2017 was 30.3\%. The total frequency of H. pylori infection among the five years and gender from September 2012-August 2013 was higher in females 214 and 122 in males. As a general, during this consecutive five years the result indicated that the frequency of the infection is highest in the first year September 2012-August 2013 (335) and decreased in the recent 4 years.

Furthermore, the $H$. pylori infection and its associated risk factors among patients undergoing upper gastrointestinal diagnosis in shashemene referral hospital from September 2016 to august 2017 were noticed. From a total of 422 study participants, $84.8 \%$ negative and overall $15.2 \%$ antigens of $H$. pylori were detected. The results showed that the number of infected female was higher $16.9 \%$ than infected males $13.5 \%$. The highest positive for the infection is seen in age group less than 20 which is $25.4 \%$. There is a significant association between the infection and this age group $(\mathrm{p}<0.05)$. In contrast, there was no sex difference (Shi et al., 2008).

Most of the study gastritis participants visiting Shashemene referral hospital from September 2016 to August 2017 have family size of $\geq 4$ that was $88.2 \%$ of which $15.3 \%$ H. pylori positive persons per house hold and only $11.8 \%$ of which $14 \% \mathrm{H}$. pylori positive study participants have family size of $<4$. The highest positive for the infection is seen in the Family size of $\geq 4$ which is $15.3 \%$. This pattern of scores is not significant $(p>0.05)$, which is parallel to other studies in Ethiopia (Abebaw et al., 2014), but this study is different from other studies elsewhere (Shmuely et al., 2003). This could be attributed to overcrowding of family and scarcity of resource (e.g source of water). For some, they were stressed when they started their new independent life. Using a statistical inference model, Strebel et al. (2010), found "more than three children living in the household", "more persons living per $\mathrm{m}^{2}$ than average", "home situated at main road" and "using well water" to be strongly associated with $H$. pylori infection. Ethiopia is one of the African countries in which the prevalence of the same infection is believed 
to be very high. This is probably attributed to the poor living conditions and overcrowding of the population (Alem Alemayehu, 2011).

Similar results were observed recently by Laszewicza et al. (2014), (Hu et al. 2013) and Zaterka et al.(2007) reported that crowding, type of drinking water, lack of toilet during childhood, lower family income, and lower educational level has a positive association. In contrast, this study found no association between $H$. pylori and socio-economic status. Similar results were observed in study in China (Shi et al., 2008) and Benin (Aguemon et al., 2005). In a study from Brazil, Dattoli et al. (2010) reported increased H. pylori infection with a larger number of siblings, nursery schooling, and housing in a street without paved roads and without flushed toilets indicating impoverished living conditions associated with poorer sanitation and overcrowding to be risk factors for $H$. pylori infection. Similarly, Fialho et al. (2010) demonstrated the number of people per room and number of children in the household as independent risk factors for H. pylori infection.

Most of the study participants earning a monthly income of $<700$ ETB 292(69.2\%) of which 40(13.7\%) are H.pylori positive and the rest $130(30.8 \%)$ of which $24(18.55 \%)$ are H.pylori positive have Monthly income of $\geq$ 700ETB. But those with $\geq 700 \mathrm{ETB}$ monthly income were relatively higher $H$. pylori positivity. As the $p$ value is greater than 0.005 , this pattern of scores is not significant. Results observed recently by Laszewicza et al. (2014), Hu et al. (2013) and Zaterka et al. (2007) showed that crowding, type of drinking water, lack of toilet during childhood, lower family income, and lower educational level has a positive association. These results are slightly similar to an important and interesting study from USA; Epplein et al. (2011) reported a high H. pylori prevalence rate of $79.0 \%$ among a subpopulation of poor Americans. Alcohol consumption is the world's third risk factor for diseases; in middle income countries, it is the greatest risk factor (WHO, 2011)

The prevalence of $H$. pylori infection by age among gastritis patients visiting shashemene referral hospital from September 2016 to August 2017 was noticed. The majority of the respondents were in the age range of 3039 years $(31.5 \%)$ and $20-29$ years $(23.5 \%)$. For this the relationship across 6 age groups of patients were examined, the highest positive for the infection is seen in age group less than 20 which is $25.4 \%$. There is a significant association between the infection and this age group $(\mathrm{p}<0.005)$. Moreover, the prevalence of $H$. pylori infection by sex among gastritis patients visiting Shashemene referral hospital in the same year was noticed and association of the infection and the different sex group is not statistically significant ( $\mathrm{p}>0.005)$. This is in agreement with the gender wise distribution of $H$. pylori seropositivity study (Khan et al. 2017), which constitute 27 (52.94\%) males and $24(47.06 \%)$ females $(\mathrm{OR}=1.537)$. In the study by Alebie $\mathrm{G}$ and Kaba D (2016), among 1371 subjects, 851(62\%) were $H$. pylori positive. However, no significant differences in the prevalence of $H$. pylori infection by gender were noted $(\mathrm{P}=0.3)$. Similarly, the prevalence of $H$. pylori infection among the study participants was $71.0 \%$. The prevalence among male was $68.5 \%$ and among female was $75.5 \%$. However, gender was not significantly associated with $H$. pylori infection $\left(\mathrm{X}^{2}=0.799 ; \mathrm{p}=0.371\right)$.

The majority of the gastritis participants visiting Shashemene referral hospital from September 2016 to August 2017 was able to read and write $73.7 \%$ while the rest were illiterate $7.1 \%$ and diploma and above $19.2 \%$ of which Illiterate $16.7 \%$ read and write $14.5 \%$, diploma and above $17.3 \%$ are $H$. pylori patients. The highest positive for the infection is seen in that diploma and above which is $17.3 \%$. Statistically significant difference was not obtained for educational attainment $\left(\mathrm{x}^{2}=0.452, \mathrm{p}=0.798>0.05\right)$ which is in agreement to studies (Shi et al., 2008, Aguemon et al., 2005) and inconsistent to other studies (Shmuely et al., 2003, Abebaw et al., 2014). Similarly, in the study by Dilnessa Tebelay and Amentie Muluwas (2017), no significant association was observed in the prevalence of $H$. pylori with family size, educational status and marital status $(\mathrm{p}>0.05)$, but a statistically significant association was observed between $H$. pylori infection and residence $(p<0.05)$, which is inconsistent with the current study.

H. pylori infection and perceived symptom's aggravating factors (smoking, drinking alcohol, Eating spicy food, hunger, stress and anger) that might aggravate gastritisvisiting shashemene referral hospital from September 2016 to August 2017 was also noticedand the highest positive for the infection is seen in patients with stress and anger habits which is $17.4 \%$ and Eating spicy food which is $16.1 \%$. As the $p$ value is greater than 0.005 , then this pattern of scores is not significant.7

In this study there was no statistical association between alcohol consumption and H. pylori infection $(\mathrm{p}>0.05)$ which is similar to other studies in South Africa (Tanih et al., 2010) andChina (Shi et al., 2008). The absence of association in this study might be due to less number of alcohol users, the type and amount of alcohol consumed has effect on the association. But this study is inconsistent with other studies done in Ethiopia (Moges et al., 2006, Abebaw et al., 2014). Despite no significant association observed, life style factors such as smoking, drinking, hunger, stress and anger, ingestions of spicy foods and drugs were found to aggravate symptoms of $H$. pylori gastritis than $H$. pylori negative gastritis. The reason for this contradictory result might be due to the difference in the type of alcoholic beverages consumed and the life time history of alcohol consumption. According to the data obtained by Megan (2006), in northern Canada prevalence of Gastritis from alcohol user 43\%, fruit and vegetable user 49\%, and smoker user was 52\%. Other studies done in Ethiopia by Moges (2006) and Abebaw et al. (2014) showed alcohol, the type and amount of alcohol consumed has effect on the association. 
The percentage of respondents who had good awareness about their personal hygiene and environmental sanitation $19.2 \%$ was lower than that of the respondents who had poor awareness about their personal hygiene and environmental sanitation $80.8 \%$. But, the highest positive for the infection is seen in respondents who had good awareness about their personal hygiene and environmental sanitation which is $21 \%$. In a study from Brazil, Dattoli et al. (2010) reported increased H. pylori infection with a larger number of siblings, nursery schooling, and housing in a street without paved roads and without flushed toilets indicating impoverished living conditions associated with poorer sanitation and overcrowding to be risk factors for $H$. pylori infection.

The percentage of respondents who had awareness about $H$. pylori were $19.2 \%$ of which $16 \%$ were $H$.pylori positive and those who had no awareness about $H$. pylori were $80.8 \%$ of which $15 \%$ were $H$. pylori positive. But, the highest positive for the infection is seen in respondents who had awareness about $H$. pylori which is $16.0 \%$. In contrast, the study at Jigjiga University, Jigjiga, Somali Regional State of Ethiopia, lack of awareness on the transmission ways of $H$. pylori was significantly associated with the prevalence of the infection $(p=0.025)$ and those who had not awareness about the transmission ways of $H$. pylori had 2.53 times higher odds of being infected with this bacterium than aware participants (Alebie G and Kaba D, 2016).

According to the study by Brown (2000), H. pylori in drinking water would be an important source of risk factor, pointing to a fecal-oral route of spread and $H$. pylori may be transmitted orally by means of fecal matter through the ingestion of waste-tainted water, so a hygienic environment could help decrease the risk of $H$. pylori infection. The source of water used by most respondents in this study was unprotected well water $178(42.2 \%)$. Only 139 (32.9\%) of the respondents were obtaining their drinking water from tap water. The highest positive for the infection is seen in respondents who used spring water which is $26.3 \%$. This pattern of scores is statistically not associated with the infection ( $\mathrm{p}>0.05)$.Using statistical inference model, Strebel et al. (2010), found "using well water" to be strongly associated with $H$. pylori infection. Brown (2000) reported that $H$. pylori may be transmitted orally by means of fecal matter through the ingestion of waste-tainted water, so a hygienic environment could help decrease the risk of $H$. pylori infection.

Most of them had not toilet $260(61.6 \%)$ of which $37(14.2 \%)$ were $H$. pylori positive and only $162(38.4 \%)$ had toilet of which $27(16.7 \%)$ was $H$. pylori positive. The highest positive for the infection is seen in respondents who had toilet which is $16.7 \%$. This pattern of scores is statistically not associated with the infection ( $\mathrm{p}>0.05)$. Results observed recently by Laszewicza et al. (2014), Hu et al. (2013) and Zaterka et al. (2007) showed that crowding, type of drinking water, lack of toilet during childhood, lower family income, and lower educational level has a positive association.

About 259 (61.4\%) of the respondents were from rural of which $14.3 \%$ were $H$. pylori positive and 163(38.6) were from urban of which $16.6 \%$ were $H$. pylori positive. The highest positive for the infection is seen in patients from urban which $16.6 \%$. This pattern of scores is statistically not associated with the infection $(\mathrm{p}>0.05)$. But, Abebaw et al. (2014) reported Slight higher prevalence observed in rural residences, but no statistically association occurred in previous studies in Ethiopia. Prevalence of $H$. pylori infection in rural residents may be attributed to factors related to the lack of safe water supply and hygiene condition in the rural part of the country.

Interestingly, the majority $244(57.8 \%$ ) of the respondents of which $14.3 \%$ were $\mathrm{H}$. pylori positive revealed that they do not share utensils with their family members and $178(42.2 \%)$ of the respondents of which $28.7 \%$ were H.pylori positive share utensils with their family members. The highest positive for the infection is seen in patients do not share utensils with their family members which are $28.7 \%$. This pattern of scores is statistically not associated with the infection ( $\mathrm{p}>0.05$ ). Lack of awareness about $H$. pyloriinfection in the study area may increase the prevalence of $H$. pylori infection; since the local people do not give care for the infection. In the same way using unprotected well water and sharing of utensils also increased the risk of transmission of bacteria within family.

From different risk factors considered in this study, marital status of the patients accounted the bigger number $(2.793$ OR; $95 \% \mathrm{CI}: \mathrm{p}=0.038<0.05$. This is statistically significant predictors or was significantly associated with H. pylori infectionwhich is in line with study in Northwest Ethiopia (Abebaw et al., 2014); in this case marital status was associated with prevalence of H.pylori, but different from other studies in Ethiopia (Moges et al., 2006) and China (Shi et al., 2008). According to study by Abebaw et al. (2014), the higher cases of gastritis among the married respondents could also be due to stress experienced as people (married couples) start new independent life. The next largestvalue was for age groups $(1.345 \mathrm{OR} ; 95 \% \mathrm{CI}$ : $\mathrm{p}=0.006<0.05$ which is also significantly associated with the infection. But, no association was found between infection and age (Aguemon et al., 2005). The third next largest value is Sharing of utensilsaccounted the bigger number $(1.431 \mathrm{OR} ; 95 \% \mathrm{CI}: \mathrm{p}=0.403>0.05$. However, this is not statistically significant predictors or is not significantly associated with $H$. pylori infection. But other risk factors like family size, monthly income, gastritis aggravate, Awareness of personal hygiene and environmental sanitation, usually wash hands with soap after latrine, awareness about $H$. pylori, having toilet,food usually makes pain and source of drinking water were not statistically significant $(\mathrm{P}>0.05)$ or were not significantly associated with $H$. pylori infection. Similarly, the prevalence H.pylori antibodies was $75.4 \%$ in the urban population and $72.3 \%$ in rural residence $(\mathrm{p}=0.459)$ and no association was found between infection and 
education level, size of house hold, economic activity or source of drinking water (Aguemon et al., 2005). This is also similar with the study at Jigjiga University, Jigjiga, Somali Regional State of Ethiopia, lack of awareness on the transmission ways of $H$. pylori was significantly associated with the prevalence of the infection $(p=0.025)$. Furthermore, those who had not awareness about the transmission ways of $H$. pylori had 2.53 times higher odds of being infected with this bacterium than aware participants (Alebie G and Kaba D, 2016). Married patients of $H$. pylori had 2.793 times higher odds of being infected with this bacterium than unmarried participants. Al-Sulami et al. (2010) reported for the first time the occurrence of $H$. pylori in treated drinking water ( $2.0 \%$ of total isolates) in Basra, Iraq. But other risk factors like Family, Income, Aggravate, pain, share, Toilet, wash were not statistically significant $(\mathrm{P}>0.05)$ or were not significantly associated with $H$. pylori infection.Consistent with the current study, from a total of 230study participants in the study at Assosa GeneralHospital, West Ethiopia, overall $48.7 \%$ antigens of H.pylori were detected and there was no significant association among age groups, family size, educational status, marital status, toilet use habit, occupation, Alcohol drinking, coffee consumption, cigarette smoking and khatchewing with $H$. pylori infection ( $>>0.05$ ), but statistically significant association was observed between $H$. pylori infection and residence $(\mathrm{p}<0.05)$ (Dilnessa Tebelay and Amentie Muluwas, 2017).

\section{CONCLUSION}

The main objective of this study was to determine the prevalence of five consecutive years of $H$. pylori infection and its associated risk factors among patients undergoing upper gastrointestinal diagnosis in Shashemene referral Hospital from September 2012 - August 2017. The design of the study was Hospital-based retrospective and crosssectional study conducted at Shashemene referral Hospital. The overall findings of this study showed that H. pylori were highly prevalent and most serious health problem in the study area. The overall prevalence of five consecutive years (September 2012 - August 2017) of $H$. pylori infection recorded in this study was $30.3 \%$. The higher positive for the infection is seen in female. The overall prevalence drops from 45.5\% in September 2012 - August 2013 to $15.6 \%$ in September 2016 - August 2017. The higher positive for the infection is seen in urban resident's patients which were $32 \%$. The majority of the patients were in the age range of $20-29$ and $\geq 60$ years. The increase in prevalence observed in this study from young age $<20$ to adult age $\geq 60$ for both sexes. The researcher found high but fluctuating prevalence of $H$. pylori infection among symptomatic patients through the five years. After screening of 422 stool samples during September 2016 to August 2017 in this study, overall 15.2\% antigens of $H$. pylori were detected (64 of 422 gastritis patients). The highest positive for the infection is seen in age group less than 20 which was $25.4 \%$. There is a significant association between the infection and age group $(\mathrm{p}<0.05)$. Moreover, association of the infection and the different sex group is not statistically significant ( $\mathrm{p}>0.005)$.

The highest positive for the infection is seen in the Family size of $\geq 4$ which is $15.3 \%$. Most of the study participants were earning a monthly income of $<700 \mathrm{ETB}$. But those with $\geq 700 \mathrm{ETB}$ monthly income were relatively higher $H$. pylori positivity. For the gastritis participants visiting shashemene referral hospital from September 2016 to August 2017, the highest positive for the infection is seen in diploma and above which is $17.3 \%$. Statistically significant difference was not obtained $(\mathrm{p}>0.05)$.

H. pylori infection and perceived symptoms that might aggravate gastritis were smoking, drinking alcohol, Eating spicy food, hunger, stress and anger. The highest positive for the infection is seen in patients with stress and anger habits which were eating spicy food, but this pattern of scores is not significant ( $\mathrm{p}>0.05)$.

Despite no significant association observed, life style factors such as smoking, drinking, hunger, stress and anger, ingestions of spicy foods and drugs were found to aggravate symptoms of $H$. pylori gastritis than $H$. pylori negative gastritis. Furthermore, despite no significant association observed, the highest positive for the infection is seen in respondents who had good awareness about their personal hygiene and environmental sanitation, good awareness about $H$. pylori, used spring water, toilet, urban and do not share utensils with their family members. Marital status of the patients $(2.793 \mathrm{OR} ; 95 \% \mathrm{CI}$ : $\mathrm{p}=0.038<0.05)$ was statistically significant predictors or was significantly associated with $H$. pylori infection. Age groups $(1.345$ OR; $95 \% \mathrm{CI}$ : $\mathrm{p}=0.006<0.05)$ was also significantly associated with the infection. Other risk factors like Sharing of utensils, family size, monthly income, gastritis aggravate, Awareness of personal hygiene and environmental sanitation, usually wash hands with soap after latrine, awareness about $H$. pylori, having toilet, food usually makes pain and source of drinking water were not significantly associated with $H$. pylori infection $(\mathrm{P}>0.05)$.

As a result of this study the prevalence of $H$. pylori infection is highest in the youngest group, because of the exacerbation of the youngest to multi substance use, excessive alcohol drinking or other related substances and environmental hygienic condition. This large group is in society vulnerable to the infection in Shashemene town and its surroundings.

\section{REFERENCES}

Abebaw W, Kibret M, Abera B. 2014. Prevalence and Risk factors of H. pylori from Dyspeptic patients in Northwest Ethiopia: A Hospital Based Cross sectional Study. Asian Pac J Cancer Prev 15 (11):4459-4463. Aguemon DB, Struelens JM, Massougbodji A, Ouendo ME. 2005. Prevalence and risk-factors for Helicobacter 
pylori infection in urban and rural Beninese populations. Clin Microbiol Infect 11: 611 -617.

Alazmi WM, Siddique I, Alateeqi N, Al-Nakib B. 2010. Prevalence of Helicobacter pylori infection among new outpatients with dyspepsia in Kuwait. BMC Gastroenterology 10:14.

Alebie G, Kaba D. 2016.Prevalence of Helicobacter Pylori Infection and Associated Factors among Gastritis Students in Jigjiga University, Jigjiga, Somali Regional State of Ethiopia. J Bacteriol Mycol Open Access 3(3): 00060. DOI: 10.15406/jbmoa.2016.03.00060.

Alem Alemayehu. 2011. Seroprevalence of Helicobacter pylori infection and its risk factors among adult patients with dyspepsia in Hawassa Teaching and Referral Hospital, South Ethiopia. Msc thesis. Addis Ababa University, Addis Ababa, Ethiopia.

Al-Sulami AA, Al-Taee AM, Juma'a MG. 2010.Isolation and identification of Helicobacter pylori from drinking water in Basra governorate, Iraq. East Mediterr Health J. 16:920-5.

Aroori S. 2001. Helicobacter pylori. Gastroenterol Today 5:131-3.

Asaka M, Kato M, Graham DY. 2010. Prevention of gastric cancer by Helicobacter pylori eradication. Intern Med. 49:633-6.

Asaka M, Kato M, Graham DY. 2010. Strategy for eliminating gastric cancer in Japan. Helicobacter. 15:486-90.

Asaka M, Kato M, Takahashi S, Fukuda Y, Sugiyama T, Ota H. 2010. Guidelines for the management of Helicobacter pylori infection in Japan.Revised edition. Helicobacter. 15:1-20.

Asrat D, Nilsson I, Mengistu Y, Ashenafi S, Ayenew K, Al-Soud WA, Wadström T, Kassa E. 2004. Prevalence of Helicobacter pylori infection among adult dyspeptic patients in Ethiopia.Ann Trop MedParasitol; 98(2):181 -189.

Assumpcao MB, Martins LC, Melo Barbosa HP, Barile KA, de Almeida SS, Assumpcao PP, et al. 2010.Helicobacter pylori in dental plaque and stomach of patients from Northern Brazil. World $J$ Gastroenterol. 16:3033-9.

Brown LM. 2000. Helicobacter pylori epidemiology and routes of transmission. Epidemiol Rev 22:283-97.

Daniel W. 2004. Biostatistics,A foundation for the analysis in the health Sciences. $7^{\text {th }}$ Ed. John Wiley and Sons (Asia) Pvt. Ltd, Singapore,pp.312.

Dattoli VC, Veiga RV, da Cunha SS, Pontes-de-Carvalho LC, Barreto ML, Alcantara-Neves NM. 2010. Seroprevalence and potential risk factors for Helicobacter pylori infection in Brazilian children. Helicobacter. 15:273-8.

Ddine LC, Vanessa Ramos, Kirsten. 2012. Factors associated with chronic gastritis in patients with presence or absence of H.pylori. Arq.bras.cir.dig vol 25no2 pauloapril-june 2012.

Debabrata M, James B \& John A. 2007.Helicobacter pylori infection and peptic ulcers.Journal of Medicine 35: 204-209.

Desta K, Asrat D, Derbie F. 2007. Sero-prevalence of Helicobactor pylori infection among health blood donors in Addis Ababa, Ethiopia. Can JGastroenterol; 21:501 -506.

Dhakhwa R, Acharya IL, Shrestha HG, Joshi DM, Lama S, Lakhey M. 2012.Histopathologic study of chronic antral gastritis.J Nepal Health Res Counc. 10:57-60.

Dilnessa Tebelay, Amentie Muluwas. 2017. Prevalence of Helicobacter pylori and risk factors among dyspepsia and non-dyspepsia adults at Assosa General Hospital, West Ethiopia: A comparative study. Ethiop. J. Health Dev. 31(1): 4-12.

Epplein M, Signorello LB, Zheng W, Peek RM, Jr, Michel A, Williams SM, et al. 2011. Race, African ancestry, and Helicobacter pylori infection in a low-income United States population. Cancer Epidemiol Biomarkers Prev. 20:826-34.

Fernandez-Tilapa G, Axinecuilteco-Hilera J, Giono-Cerezo S, Martinez-Carrillo DN, Illades-Aguiar B, RomanRoman A. 2011. Genotypes in oral cavity and Helicobacter pylori seropositivity among adults without dyspepsia. Med Oral Patol Oral Cir Bucal. 16:175-80.

Fialho AB, Braga-Neto MB, Guerra EJ, Fialho AM, Fernandes KC, Sun JL, et al. 2011.Low prevalence of $H$. pylori Infection in HIV-positive patients in the northeast of Brazil. BMC Gastroenterol. 11:13

Fialho AM, Braga AB, Braga Neto MB, Carneiro JG, Rocha AM, Rodrigues MN, et al. 2010. Younger siblings play a major role in Helicobacter pylori transmission among children from a low-income community in the Northeast of Brazil. Helicobacter. 15:491-6.

Ghazzawi IM, Obidat NA. 2004. The role of Helicobacter pylori infection in the pathogenesis of chronic urticaria. Pak J Med Sci. 20:101-4.

Gong YH, Sun LP, Jin SG, Yuan Y. 2010. Comparative study of serology and histology based detection of Helicobacter pylori infections: a large population-based study of 7,241 subjects from China. Eur J Clin Microbiol Infect Dis. 29:907-11.

Graham DY, Sung JY. 2006. Helicobacter pylori. Sleisenger and Fordtran's Gastrointestinal and Liver Disease. In: Feldman M, Friedman LS, Brandt LJ, editors, 2006. Pathophysiology, Diagnosis, Management. $7^{\text {th }}$ ed. Philadelphia, WB Saunders Co, pp. 1049-66. 
Harvey RF, Lane JA, Nair P, Egger M, Harvey I, Donovan J, et al. 2010. Clinical trial: prolonged beneficial effect of Helicobacter pylori eradication on dyspepsia consultations - the Bristol Helicobacter Project. Aliment Pharmacol Ther. 32:394-400.

Hu D, ShaoJ, Wang L, Zheng H, Xu Y, Song G, Liu Q. 2013. Prevalence and risk factors of Helicobacter pylori infection in Chinese maritime workers. Ann Hum Biol, 40 (6): 4726

Hunt RH, Xiao SD, Megraud F, Leon-Barua R, Bazzoli F, van der Merwe S, et al. 2011. Helicobacter pylori in developing countries.World Gastroenterology Organization Global Guidelines; World Gastroenterology Organization.J Gastrointestinal Liver Dis. 20:299-304.

Jafarzadeh A, Ahmedi-Kahanali J, Bahrami M, Taghipour Z. 2017.Sero-prevalence of anti-Helicobacterpylori and anti-CagA antibodies among healthy children according to age, sex, ABO blood groups and Rh status in southeast of Iran.Turk JGastroenterol 18(3):165-171.

Jafri W, Yakoob J, Abid S, Siddiqui S, Nizami SASQ. 2010. Helicobacter pylori infection in children: populationbased age-specific prevalence and risk factors in a developing country. ActaPcediatrica 99:279-282.

Janjetic MA, Goldman CG, Balcarce NE, Rua EC, Gonzalez AB, Fuda JA, et al. 2010. Iron, zinc, and copper nutritional status in children infected with Helicobacter pylori. J Pediatr Gastroenterol Nutr. 51:85-9.

Khan S, Beevi PNF, Husain M, Hassan MJ, Jetley S. 2017.Helicobacter pylori Infection and Associated Risk Factors in Patients with upper Gastrointestinal Symptoms. Int Arch BioMed Clin Res. 2017; 3(1 ):3843.DOI:10.21276/iabcr. 3.1 .11

Kim do H, Jung HM, Hwang YJ, Ahn YS, Mun JS, Myoung BH, et al. 2010. Culture and polymerase chain reaction of Helicobacter pylori from rectal and terminal ileal fluid after polyethylene glycol (colyte) ingestion in healthy adults with positive urea breathe test. Korean J Gastroenterol. 56:27-32.

Koch A, Krause TG, Krogfelt K, Olsen OR, Fischer TK, Melbye M. 2005.Sero-prevalence and Risk Factors for Helicobacter pylori Infection in Greenlanders.Helicobactor.10(5): 433-342.

Kumar R, Bano G, Kapoor B, Sharma S, Gupta Y. 2006. Clinical profile in Helicobacter pylori positive patients in Jammu. J.K. Science; 8(3): 148-150.

Laszewicza W, Iiwanczakb F, Iwancazakb B. 2014. Seroprevalence of Helicobacter pylori infection in Polish children depending on socioeconomic status and living conditions. Adv. Med Sci. 59(1):147-50.

Linke S, Lenz J, Gemein S, Exner M, Gebel J. 2010. Detection of Helicobacter pylori in biofilms by real-time PCR.Int J Hyg Environ Health. 213:176-82.

Malfertheiner P; Megraud F; O'Morain C. 2007. Current concepts in the Management of Helicobacter pylori infection the Maastricht III Consensus Report "Current concepts in the management of Helicobacter pylori infection: the Maastricht III Consensus Report”. Gut 56: 772-81.

Malfertheiner P; Megraud F; O’Morain CA; Atherton J; Axon AT; Bazzoli F; Gensini GF; Gisbert JP; Graham DY, Rokkas T, El-Omar EM; European Helicobacter study Group , 2012. Management of Helicobacter pylori infection the Maastricht IV/Florence Consensus Report Gut 61: 646-64.

Mathewos B, Moges B, Dagnew M. 2013. Sero-prevalence and trend of Helicobacter pylori infection in Gondar University Hospital among dyspeptic patients, Gondar, northwest Ethiopia.BMC Research Notes 6:346.

McJunkin B, Sissoko M, Levien J, Upchurch J, Ahmed A. 2011. Dramatic Decline in Prevalence of Helicobacter pylori and Peptic Ulcer Disease in an Endoscopy-referral Population. Am J Med. 124:260-4.

Megan Gohnson. 2006. Dietary factors and prevalence of severe gastritis in an H. pylori infected population from northern Canada. M.Sc thesis. Canada.

Mizuno S, Miki I, Ishida T, Yoshida M, Onoyama M, Azuma T, et al. 2010. Prescreening of a high-risk group for gastric cancer by serologically determined Helicobacter pylori infection and atrophic gastritis. Dig Dis Sci. $55: 3132-7$.

Moges F, Kassu A, Mengistu G, Adugna S, Andualem B, Nishikawa T. 2006. Sero-prevalence of Helicobacter pylori in dyspeptic patients and its relationship with HIV infection, ABO blood groups and life style in a university hospital, Northwest Ethiopia.World J Gastroenterol 12(12):1957- 1961.

Muhsen K, Athamna A, Bialik A, Alpert G, Cohen D. 2010. Presence of Helicobacter pylori in a sibling is associated with a long-term increased risk of $H$. pylori infection in Israeli Arab children. Helicobacter. 15:108-13.

Naja F, Kreiger N, Sullivan T. 2007. Helicobacter pylori infection in Ontario: Prevalence and risk factors. Can J Gastroenterol 21(8):501 -506.

Nakajima S, Nishiyama Y, Yamaoka M, Yasuoka T, Cho E. 2010. Changes in the prevalence of Helicobacter pylori infection and gastrointestinal diseases in the past 17 years. $J$ Gastroenterol Hepatol. 25(Suppl 1):S99-110

Nam SY, Choi IJ, Ryu KH, Kim BC, Kim CG, Nam BH. 2010. Effect of Helicobacter pylori infection and its eradication on reflux esophagitis and reflux symptoms. Am J Gastroenterol. 105:2153-62.

Namiot DB, Leszczynska K, Namiot Z, Chilewicz M, Bucki R, Kemona A. 2010. The occurrence of Helicobacter pylori antigens in dental plaque; an association with oral health status and oral hygiene practices. Adv Med 
Sci. 55:167-71.

Omunakwe HE, Madubuike OC, Nwosu SO, Pughikumo CO, Nwauche CA. 2011. Gastric mucosa-associated lymphoid tissue: The need for prompt histologic diagnosis. Ann Trop Med P//88778/-1

ublic Health. 4:113-5.

Ozbek A, Ozbek E, Dursun H, Kalkan Y, Demirci T. 2010. Can Helicobacter pylori invade human gastric mucosa? An in vivo study using electron microscopy, immunohistochemical methods, and real-time polymerase chain reaction.J Clin Gastroenterol. 44:416-22.

Ozdil K, Sahin A, Kahraman R, Yuzbasioglu B, Demirdag H, Calhan T, et al. 2010. Current prevalence of intestinal metaplasia and Helicobacter pylori infection in dyspeptic adult patients from Turkey. Hepatogastroenterology. 57:1563-6.

Ozen A, Furman A, Berber M, Karatepe HO, Mutlu N, Saricoban HE, et al. 2011. The effect of Helicobacter pylori and economic status on growth parameters and leptin, ghrelin, and insulin-like growth factor (IGF)I concentrations in children. Helicobacter. 16:55-65.

Pandeya N, Whiteman DC. 2011. Prevalence and determinants of Helicobacter pylori sero-positivity in the Australian adult community. J Gastroenterol Hepatol. Mar 28; doi: 10.1111/j.1440-1746.2011.06726.x.

Parkin DM, Pisani P, Ferlay J. 1999.Global cancer statistics.CA Cancer J Clin. 49:33_ 64

Rasmussen LT, Labio RW, Gatti LL, Silva LC, Queiroz VF, Smith Mde A, et al. 2010. Helicobacter pylori detection in gastric biopsies, saliva and dental plaque of Brazilian dyspeptic patients. Mem Inst Oswaldo Cruz. 105:326-30.

Rastogi M, Rastogi D, Singh S, Agarwal A, Priyadarshi BP, Middh T . 2015. Prevalence of Helicobacter pylori in asymptomatic adult patients in a tertiary care hospital: A cross

Samra ZQ, Javaid U, Ghafoor S, Batool A, Dar N, Athar MA. 2011. PCR assay targeting virulence genes of Helicobacter pylori isolated from drinking water and clinical samples in Lahore metropolitan, Pakistan. $J$ Water Health. 9:208-16.

Schimke K, Chubb SA, Davis WA, Davis TM. 2010. Helicobacter pylori cytotoxin-associated gene-A antibodies do not predict complications or death in type 2 diabetes: the Fremantle Diabetes Study. Atherosclerosis. 212:321-6.

Sepulveda AR, Graham DY. 2002. Role of Helicobacter pylori in gastric carcinogenesis. Gastroenterol Clin North Am. 31:517-35.

Shi R, Xu S, Zhang H, Ding Y, Sun G, Huang X, et al. 2008. Prevalence and Risk Factors for Helicobacter pylori Infection in Chinese Populations.Helicobacter 13:157-165.

Shiomoyama T and Kato. 2009. Applications of a monoclonical antibody-based stool antigen test to evaluate the results of $H$. pylori eradication therapy. 62(3): 225.

Shmuely H, Obure S, Passaro DJ, Abuksis G, Yahav J, Fraser G, et al. 2003. Dyspepsia Symptoms and Helicobacter pylori Infection, Nakuru, Kenya. Emerging Infectious Diseases 9(9):1103-7.

Silva DG, Tinoco EM, Rocha GA, Rocha AM, Guerra JB, Saraiva IE, et al. 2010. Helicobacter pylori transiently in the mouth may participate in the transmission of infection. Mem Inst Oswaldo Cruz. 105:657-60

Sonnenberg A, Lash RH, Genta RM. 2010. A national study of Helicobactor pylori infection in gastric biopsy specimens. Gastroenterology. 139:1894-901. e2; quiz e12.

Stenstrom B, Mendis A, Marshal B. 2008. "Helicobacter pylori- the latest in diagnosis and treatment". Aust Fam Physician 37: 608-12

Stingl K, uhleman e-m, schmidr, altendorf k, baker EP. 2002. Energetics of Helicobacter pylori and its implications for the mechanism of urease-dependent acid tolerance at PH 1. Journal Bacteriol, 184: 3053-3060

Strebel K, Rolle-Kampczyk U, Richter M, Kindler A, Richter T, Schlink U. 2010. A rigorous small area modelingstudy for the Helicobacter pylori epidemiology. Sci Total Environ. 408:3931-42.

Suk F, Lien G, Yu T, Ho Y. 2011. Global trends in Helicobacter pylori research from 1991-2008 analyzed with the Science Citation Index Expanded. Eur J GastroenterolHepatol. 23:295-301.

Tadege T, Mengistu Y, Desta K, Asrat D. 2005. Seroprevalence of Helicobacter pylori Infection in and its Relationship with ABO Blood Groups.Ethiop. J. Health Dev.19(1):55-59.

Tadesse E, Daka D, Yemane D, Shimelis T. 2014. Seroprevalence of Helicobacter pylori infection and its related risk factors in symptomatic patients in southern Ethiopia.BMC Research Notes; 7:834.

Take S, Mizuno M, Ishiki K, Yoshida T, Ohara N, Yokota K, et al. 2011. The long-term risk of gastric cancer after the successful eradication of Helicobacter pylori. J Gastroenterol. 46:318-24.

Tanih NF, Okeleye BI, Ndip LM, Clarke AM, Naidoo N, Mkwetshana N, et al. 2010. Helicobacter pylori prevalence in dyspeptic patients in the Eastern Cape province-race and disease status. $S$ Afr Med J;100:734737.

Tsega E, Gebre W, Manley P, Asfaw T. 1996. Helicobacter pylori, gastritis and non-ulcer dyspepsia in Ethiopia patients. Ethiop Med Journal. 34: 65-71.

Veldhuyzen van zantel SJ. 1995. Do socioeconomic status, marital status and occupation influence the prevalence 
of Helicobacter pylori infection? Aliment PharmacolTher. 9(Suppl 2):41-4.

World Health Organization. 2011. Global status report on alcohol and health. ISBN 9789241564151, WHO Library Cataloguing-in-Publication Data (NLM classification: WM 274).

Zaterka S, Eisig JN, Chinzon D, Rothstein W. 2007. Factors related to Helicobacter pylori prevalence in an adult population in Brazil. Helicobacter 12 (1):828

Zous QH, Li RQ. 2011. Helicobacter pylori in the oral cavity and gastric mucosa: a meta-analysis. J Oral Pathol Med. 40:317-24. 